\author{
Maciej KOPCZYŃSKI ${ }^{1}$ \\ Jolanta KOSZELEW ${ }^{2}$ \\ Bogusz WIŚNICKI ${ }^{3}$ \\ Piotr WOLEJSZA ${ }^{4}$
}

\title{
NAUCZANIE PRZEDSIĘBIORCZOŚCI NA KIERUNKACH TECHNICZNYCH W POLSKICH UCZELNIACH
}

\begin{abstract}
Artykuł jest efektem dwuletniej współpracy i badań, które dwie polskie uczelnie Akademia Morska w Szczecinie i Politechnika Białostocka wraz z partnerami zagranicznymi, prowadzą $w$ ramach projektu MELES (More Entrepreneurial Life at European Schools) finansowanego z Programu Erasmus+. Głównym rezultatem projektu jest program nauczania przedsiębiorczości dla multidyscyplinarnej grupy studentów kierunków technicznych oraz jego implementacja na uczelniach wyższych. Autorzy artykułu przedstawili uwarunkowania nauczania akademickiego nauk o przedsiębiorczości oraz doświadczenia w tym zakresie przodujących ośrodków akademickich w Europie i USA. Omówione przykłady „dobrych praktyk” pochodzą z uczelni: Stanford University i University of California w USA oraz Delft University of Technology w Holandii, Technical University in Munich w Niemczech, Finnish Polytechnics Entrepreneur-Ship Network w Finlandii. Na przykładzie wybranych technicznych kierunków nauczania $\mathrm{z}$ realizowanych na trzech uczelniach (Akademia Morska w Szczecinie, Politechnika Białostocka i Politechnika Warszawska) zbadano zmiany dokonane w programach nauczania w latach 2009-2015. Scharakteryzowano formę realizacji i treści programowe przedmiotów nauczania przedsiębiorczości prowadzonych na studiach inżynierskich wybranych uczelni w roku akademickim 2015/2016. Na tej podstawie wyciągnięto wnioski o charakterze szczegółowym i ogólnym oraz sformułowano rekomendacje dla rad programowych uczelni technicznych w zakresie opracowania oraz implementacji przedmiotów z obszaru przedsiębiorczości. Szczególną uwagę autorzy poświęcają aspektowi multidyscyplinarności i wynikającym $z$ niej barierom implementacji przedmiotów. Analiza wykazała brak spójnej strategii wdrażania przedmiotów nauczania przedsiębiorczości. Taka strategia jest bardzo potrzebna, a przedmioty związane $\mathrm{z}$ przedsiębiorczością powinny być realizowane $\mathrm{w}$ synergii z całym ekosystem wspierania biznesu.

Słowa kluczowe: przedsiębiorczość, proces nauczania, szkoły wyższe, multidyscyplinarność.
\end{abstract}

\footnotetext{
${ }^{1}$ Dr inż. Maciej Kopczyński, Wydział Informatyki, Politechnika Białostocka, ul. Wiejska 45A, 15-351 Białystok, tel.+48857469050, e-mail: m.kopczynski@ pb.edu.pl.

${ }^{2}$ Dr Jolanta Koszelew, Wydział Informatyki, Politechnika Białostocka, ul. Wiejska 45A, 15-351 Białystok, tel. +48857469050, e-mail: j.koszelew@ @b.edu.pl.

${ }^{3}$ Dr inż. Bogusz Wiśnicki, Wydział Inżynieryjno-Ekonomiczny Transportu, Akademia Morska w Szczecinie, ul. H. Pobożnego 11, 70-507 Szczecin, tel. +48914809640, e-mail: b.wisnicki@am.szczecin.pl.

${ }^{4}$ dr inż. kpt. ż.w. Piotr Wołejsza, Wydział Nawigacyjny, Akademia Morska w Szczecinie, ul. Wały Chrobrego 1/2, 70-500 Szczecin, tel. +48914809443, e-mail: p.wolejsza@am.szczecin.pl.
} 


\section{UWARUNKOWANIA NAUCZANIA PRZEDSIEBIORCZOŚCI}

Dziś nikt nie ma wątpliwości, że przedsiębiorczy absolwent szkoły wyższej ma dużo większe szanse na lepsze wejście na rynek pracy. Bez względu na dział gospodarki maleje liczba miejsc pracy w dużych przedsiębiorstwach i instytucjach państwowych. O szansach na zatrudnienie absolwentów decyduje coraz częściej poziom nabytych umiejętności przekrojowych, takich jak przedsiębiorczość, innowacyjność i kreatywność. To właśnie tego typu umiejętności stają się kluczowym kapitałem w rozwoju prywatnych podmiotów gospodarczych działających na bardzo konkurencyjnym rynku produktów i usług.

Badania dowodzą, że coraz mniejsze znaczenie ma rodzaj zdobytego wykształcenia potwierdzonego dyplomem ukończenia uczelni, a coraz większą rolę odgrywa zgodność zdobytej wiedzy i umiejętności z oczekiwaniami potencjalnych pracodawców. Pożądane umiejętności bez względu na stanowisko pracy można zaliczyć do samoorganizacyjnych (samodzielność, zarządzanie czasem, podejmowanie decyzji, przejawianie inicjatywy, odporność na stres) i interpersonalnych (komunikatywność, współpraca w grupie, rozwiązywanie konfliktów międzyludzkich) ${ }^{5}$. Bez względu na podmiot i formę zatrudnienie, kluczowa cecha, jaką jest przedsiębiorczość, powinna być rozumiana jako sposób działania, polegający na skłonności podejmowania nowych, ryzykownych i niekonwencjonalnych przedsięwzięć oraz na wykazywaniu inicjatywy $\mathrm{w}$ ich poszukiwaniu i wdrażaniu w życie ${ }^{6}$. Można uznać, że przedsiębiorczość jest nowatorstwem polegającym na poszukiwaniu odmienności w porównaniu z tym, co robią inni, znajdowaniu bardziej skutecznych sposobów działania na rynku, dążenia do osiągnięcia wyższej użyteczności produktów i usług oraz większej efektywność gospodarowania. Jest ona ze swej natury działalnością konkurencyjną, w stosunku do postępowania innych ${ }^{7}$.

Mając na uwadze przytoczone wyżej definicje, można wysnuć wniosek, że nauczanie przedsiębiorczości to przede wszystkim kompleksowy proces wykształcenia przedsiębiorczych cech wśród studentów. Nie da się ich stworzyć tylko poprzez dostarczanie wiedzy $\mathrm{z}$ zakresu szeroko rozumianej gospodarki. Nauczyciel przedsiębiorczości powinien być przede wszystkim mentorem, trenerem, inspiratorem. Oczywiście nie może on działać tylko i wyłącznie w zakresie umiejętności miękkich. Mentoring musi być poparty „twardą” wiedzą, ale powinna być ona przekazywana „między wierszami”, na przykład przy okazji realizowanych projektów. Standardowe formy zajęć w zakresie przedsiębiorczości na uczelni nie satysfakcjonują studentów i nie kształcą efektywnie założonych umiejętności a jedynie przekazują wiedzę. Na podstawie przeprowadzonych wśród absolwentów badań, stwierdzono że wiedza nabyta podczas studiów w niewielkim stopniu jest przydatna w życiu zawodowym ${ }^{8}$. Absolwenci oczekiwali większej liczby zajęć praktycznych, zajęć przygotowujących do zawodu w tym prowadzenia własnej działalności gospodarczej.

\footnotetext{
${ }^{5}$ M. Kocór, A. Strzebońska, Zapotrzebowanie na pracowników, Warszawa, 2014, s. 43-47.

${ }^{6}$ J. Kortan, Podstawy ekonomiki i zarządzania przedsiębiorstwem, Warszawa, 1997, s. 77-78.

${ }^{7}$ K. Fabiańska, Planowanie rozwoju przedsiębiorstwa, Warszawa, 1986, s. 11-14.

${ }^{8}$ F. Majka, Analiza przestrzenna zatrudnienia absolwentów Wydziału Nawigacyjnego kierunku Geodezja i Kartografia, praca inżynierska, Wydział Nawigacyjny, Akademia Morska w Szczecinie, Szczecin 2016, s. 47.
} 
Oczekiwania studentów wpisują się w rekomendacje zawarte w raporcie Komisji Europejskiej dotyczącym przedsiębiorczości w szkolnictwie wyższym, który został opublikowany w roku $2008^{9}$. Według raportu działania, które powinny być podjęte przez uczelnie obejmują:

- określenie strategii i planu działań w zakresie nauczania i badań w zakresie przedsiębiorczości,

- $\quad$ wprowadzenie nauczania przedsiębiorczości na wszystkich kierunkach studiów oraz w ramach poradnictwa zawodowego,

- wdrożenie systemu motywacyjnego dla pracowników wydziałów w zakresie wspierania studentów zainteresowanych przedsiębiorczością i tworzeniem nowych firm. Należy uznać również wartość naukową badań i działań w dziedzinie przedsiębiorczości,

- wspieranie spontanicznych inicjatyw studentów w zakresie przedsiębiorczości, w tym ustanowienie kredytów akademickich dla działań nad projektami biznesowymi (np. na opracowanie planów biznesowych.

W przypadku uczelni w Polsce, a w szczególności uczelni technicznych, wdrożenie oczekiwanych działań napotyka na duże przeszkody, gdyż wiąże się wprost z rezygnacją $\mathrm{z}$ tradycyjnego modelu kształcenia. Duże obawy władz budzi zmiana profilu nauczania z kierunkowego na multidyscyplinarny, który wymusza współpracę między konkurencyjnymi wydziałami i uczelniami. Wreszcie, trudna do zaakceptowania jest elastyczna formuła organizacji zajęć opartych o warsztaty i projekty, ale również praktyki poza uczelnią i prezentacje projektów i pomysłów biznesowych z udziałem potencjalnych inwestorów.

Sprzymierzeńcem zmian w zakresie wprowadzania nauczania przedsiębiorczości jest obowiązująca od 2012 r. ustawa Prawo o szkolnictwie wyższym. Możemy dziś mówić o polityce wsparcia dla nauczania akademickiego przedsiębiorczości wyrażaną w nowych aktach prawnych i strategiach właściwego ministerstwa. W ramach Polityki Nowej Szansy z 2016 rekomenduje się budowanie wśród studentów wszystkich kierunków studiów proprzedsiębiorczej postawy i rozwijanie u studentów kompetencji przedsiębiorczych $^{10}$. Obecnie trwają prace nad nową ustawą o szkolnictwie wyższym, która, z dużym prawdopodobieństwem, wprowadzi przepisy wymuszające konkretne i spójne z polityką „urynkowienia” uczelni zmiany w jej ofercie programowej.

Celem artykułu jest analiza procesu realizacji polityki wsparcia dla przedsiębiorczości na uczelniach w Polsce. Autorzy skoncentrowali się na zmianach programów nauczania na kierunkach technicznych. Punktem odniesienia analizy są działania realizowane w wybranych ośrodkach akademickich w Europie i USA oraz efekty międzynarodowego projektu MELES. Głównym projektu MELES realizowanym w ramach programu Erasmus+ jest otwarcie uczelni na współpracę $\mathrm{z}$ otoczeniem $\mathrm{i}$ wprowadzenie nowej metodyki nauczania przedsiębiorczości studentów uczelni technicznych ${ }^{11}$.

\footnotetext{
${ }^{9}$ S. Lilischkis et al., Supporting the Entrepreneurial Potential of Higher Education, Final Report, 2015, www.minedu.fi, s. 62-70 (dostęp: 21.04.2016 r.).

${ }^{10}$ Rekomendacja MNiSW dot. Polityki Nowej Szansy, Ministerstwo Nauki i Szkolnictwa Wyższego, 9 lutego 2016 r., http://www.nowaszansa.gov.pl/, (dostęp: 21.04 .2016 r.).

${ }^{11}$ MELES (More Entrepreneurial Life at European Schools), program realizowany w ramach Partnerstw Strategicznych na Rzecz Szkolnictwa Wyższego - program Erasmus+, www.melesproject.eu, (dostęp: 21.04.2016 r.).
} 


\section{PRZEDSIĘBIORCZOŚĆ AKADEMICKA W EUROPIE I USA}

Wiedząc, na jakie wyzwania i ograniczenia napotykają autorzy w fazie implementacji przedmiotu Przedsiębiorczość opracowanego $\mathrm{w}$ ramach projektu MELES, warte przeanalizowania są najważniejsze wnioski $\mathrm{z}$ dobrych praktyk $\mathrm{w}$ realizacji przedmiotów związanych $\mathrm{z}$ przedsiębiorczością na uczelniach technicznych, w rozwiniętych gospodarczo krajach Europy ${ }^{12}$ i USA $^{13}$.

W Delft University Of Technology (DUT, Holandia) od 10 lat działa Centrum Przedsiębiorczości, które zajmuje się realizacją i ciągłym udoskonalaniem przedmiotów z zakresu przedsiębiorczości. Przedmioty te wprowadzone są do programów nauczania wszystkich 8 wydziałów DUT. Nie jest to pojedynczy kurs ale cały pakiet przedmiotów obowiązkowych kształtujących zarówno umiejętności miękkie (tj. przywództwo, kreatywność, współpraca w zespołach projektowych) jak i przekazujących merytoryczną wiedzę biznesową (tj. projektowanie biznesu, analityka biznesowa). Kluczowym czynnikiem sukcesu w rozwoju edukacji przedsiębiorczości na DUT był fakt, iż 80\% dziekanów była zatrudniona już w latach 90 . w sektorze prywatnym. Dzięki temu dziekani aktywnie wspierali i wspierają edukację przedsiębiorczości swoich studentów i pracowników. Działalność Centrum Przedsiębiorczości DUT jest finansowana w 90\% z dotacji rządowej oraz w $10 \%$ z funduszy prywatnych.

Technical University in Munich (TUM, Niemcy) już w 1999 roku uruchomił spółkę w celu komercjalizacji projektów B+R realizowanych na uczelni. Spółka ta zajęła się również edukacją przedsiębiorczości na uczelni a jej obowiązki w tym zakresie przejęło w 2002 r. Centrum Przedsiębiorczości TUM. Wszelkie aktywności związane z przedsiębiorczością akademicką (edukacja studentów, akceleracja i inkubacja nowych firm) są finansowane dzięki prężnie działającej na całym świecie sieci ok. 30000 absolwentów TUM. W 2004 roku Centrum Przedsiębiorczości TUM uruchomiło program Manage\&More, w którym biorą udział najlepsi studenci i doktoranci TUM. Program kładzie nacisk na takie obszary nauczania przedsiębiorczości jak: innowacyjność, pozyskiwanie i efektywne wykorzystanie zasobów do realizacji projektów, gotowość na ponoszenie ryzyka w trakcie realizacji projektów oraz kreatywność.

W Finnish Polytechnics Entrepreneur - Ship Network (FINPIN, Finlandia) od 2005 roku działają uczelnie techniczne oraz uniwersytety zajmujące się naukami stosowanymi. FINPIN rozwija nie tylko międzywydziałową, ale i międzyuczelnianą Szkołę Biznesu Sukcesyjnego (Business Succession School). Powodem uruchomienia szkoły był problem z sukcesją czyli przekazaniem biznesu kolejnym pokoleniom przedsiębiorców, ale dzięki temu do dziś rolę nauczycieli przedmiotów w ramach szkoły przyjmują menadżerowie firm. Inną interesującą aktywnością FINPIN jest uruchomienie szkoleń dla nauczycieli akademickich ze stopniem doktora, którzy chcą uczyć przedsiębiorczości na swoich uczelniach. Kluczowym elementem tego programu jest odbycie co najmniej rocznej praktyki w lokalnym startupie technologicznym - najlepiej własnym.

\footnotetext{
${ }^{12}$ Entrepreneurship Education: A Global Consideration From Practice to Policy Around the World, WISE - World Summit for Education, 2016, s. 43-53, http://www.wise-qatar.org/ (dostęp: 21.04.2016 r.).

${ }^{13}$ Entrepreneurship in American Higher Education, Report from the Kauffman Panel on Entrepreneurship Curriculum in Higher Education, 2008, http://www.kauffman.org, s. 9-14 (dostęp: 21.04.2016 r.).
} 
W Stanford University (USA) w ramach bloku przedmiotów kształtujących umiejętności przekrojowe studenci wszystkich wydziałów spotykają się na wspólnych zajęciach z: przywództwa, innowacji, przedsiębiorczości, kreatywności oraz własności intelektualnej. Podstawową metodyką pracy ze studentami jest projekt. W ramach campusu uczelni działa ogólnodostępna przestrzeń o nazwie d.school (http://dschool.stanford.edu/), która umożliwia studentom pracę nad projektami zarówno w obszarze rozwoju technologii, jak i projektowania produktów i usług pod kątem potrzeb użytkownika.

W University Of Californi (Berkeley, USA) zajęcia z przedsiębiorczości realizowane są w ramach działającej na uczelni szkoły biznesu - Haas School of Business. Oferuje ona dwie możliwości realizacji zajęć powiązanych z biznesem. Jedna z nich to uczestnictwo w pojedynczych przedmiotach związanych z przywództwem, technikami prezentacji, negocjacjami, kreowaniem zespołów czy projektowaniem i opisem biznesu. Ta opcja jest oferowana studentom wszystkich kierunków studiów. Druga możliwość skorzystania z zajęć prowadzonych w Haas to zapisanie się na jeden z kierunków studiów związanych z zarządzaniem i biznesem. Studia prowadzone są na wszystkich poziomach - począwszy od pierwszego stopnia na podyplomowych skończywszy.

Oprócz powyższych przykładów warto zauważyć, opierając się na raporcie Komisji Europejskiej, że w wielu krajach europejskich zostały opracowane narodowe spójne strategie modernizacji programów nauczania przedsiębiorczości na wszystkich etapach edukacji: od przedszkola (np. w Holandii) poprzez szkoły podstawowe i średnie, aż do studiów wyższych i podyplomowych ${ }^{14}$. Wydaje się, że takiej spójnej strategii brakuje w Polsce, czego efektem jest sytuacja, w której studenci prezentują bardzo różny poziom wiedzy i umiejętności z zakresu biznesowego widoczny na starcie realizacji przedmiotów związanych z przedsiębiorczością na uczelni. Polskie uniwersytety powinny się dużo aktywniej niż dotąd włączyć w proces budowy systemu startupowego. Centra Przedsiębiorczości rodem z Holandii, Niemiec czy USA, oczywiście zaadoptowane do polskich potrzeb, powinny powstać w każdej dużej uczelni albo w grupie uczelni, w każdym mieście wojewódzkim. Tego typu centra, a nie poszczególne wydziały, powinny kompleksowo zajmować się edukacją przedsiębiorczości, nie tylko w ramach zajęć realizowanych $\mathrm{w}$ programach studiów, ale również jako wsparcie coachingowe i mentorskie realnych projektów.

\section{ANALIZA PORÓWNAWCZA PROGRAMÓW NAUCZANIA} WYBRANYCH KIERUNKÓW TECHNICZNYCH W POLSCE

Przedmioty $\mathrm{z}$ grupy nauk o przedsiębiorczości nie należą do standardowych przedmiotów w programach nauczania wyższych uczelni. W zależności od koncepcji, jaką przyjęły rady i inne gremia programowe wydziałów przedmioty te pod różnymi nazwami zaliczane są do przedmiotów ogólnych, kierunkowych lub specjalistycznych. Te i inne różnice $\mathrm{w}$ podejściu do realizacji treści programowych z zakresu przedsiębiorczości można zaobserwować analizując programy nauczania uczelni technicznych w Polsce. Tego rodzaju zestawienie analizowanych przedmiotów pokazuje tabela 1 przygotowana w oparciu o aktualne karty przedmiotów na trzech uczelniach: Politechniki Warszawskiej, Politechniki Białostockiej i Akademii Morskiej w Szczecinie. Dobór uczelni jest

\footnotetext{
${ }^{14}$ Entrepreneurship in higher education, especially within non-business studies, Final Report of the Expert Group, European Commission, 2008, http://europa.eu.int, s. 15-21 (dostęp: 21.04.2016 r.).
} 
reprezentatywny dla wielkości i oferty programowej szkół wyższych technicznych w Polsce. Politechnika Warszawska ma bardzo bogatą ofertę programową, duże doświadczenie edukacyjne i największe zasoby kadrowo-techniczne. Nieco mniejszą ofertę programową i skoncentrowaną na kilku przodujących kierunkach nauczania ma Politechnika Białostocka. Uczelnia ta jest jednym z liderów w Polsce w liczbie startupów akademickich i uznanych na rynku międzynarodowym inicjatyw biznesowych studentów. Akademia Morska w Szczecinie jest małą uczelnią wysoce wyspecjalizowaną w zakresie edukacji morskiej, która z uwagi na swoją specyfikę wymaga większej standaryzacji w odniesieniu do skali globalnej.

Zestawienie w tabeli 1 pokazuje, że analizowanym uczelniom udało się wdrożyć do swoich programów przedmioty nauczania przedsiębiorczości, lecz ich forma realizacji budzi obawy o skuteczność nauczania. Obserwacje wynikające z analizy programów wyglądają następująco:

- przedmioty w zdecydowanej większości przypadków są realizowane w grupach audytoryjnych, tj. powyżej 30 studentów;

- zajęcia są realizowane jako przedmioty obowiązkowe lub obieralne, co nie wydaje się mieć uzasadnienia ze względu na kierunek nauczania ani pozycję przedmiotu w siatce godzin. Regułą jest realizacja na pierwszym lub ostatnim roku studiów;

- brak łączenia grup studenckich pomiędzy wydziałami. Preferowane jest łączenie grup różnych specjalności w ramach na kierunku poprzez realizację zajęć, jako przedmiot obowiązkowy lub obieralny dla kierunku;

- realizacja treści programowych zawartych w dostępnych sylabusach jest w większości przypadków sprzeczna $\mathrm{z}$ formą realizacji zajęć, tj. w grupach audytoryjnych planowana jest praca w zespołach, które pracują nad biznesplanami lub projektami przedsięwzięć;

- treści programowe w wielu przypadkach są zbyt obszerne w stosunku do zaplanowanej liczby godzin (np. Przedsiębiorczość w praktyce), a w kilku innych przypadkach zdecydowanie zawężają tematykę (np. Planowanie przedsięwzięć biznesowych i przedsiębiorczość innowacyjna; Przedsiębiorczość). Często też wydają się być zbyt zawężone tematycznie w stosunku do potrzeb (np. Działalność gospodarcza - źródła finansowania, regulacja zobowiązań podatkowych; Samozatrudnienie);

- widać liczne przykłady nauczania projektowego z wykorzystaniem studiów przypadków i modeli biznesowych oraz metod myślenia kreatywnego, lecz brak jest informacji o odpowiednim zapleczu technicznym dla tych zajęć (np. np. specjalistyczne oprogramowanie, pomoce dydaktyczne do zajęć warsztatowych, prototypownia lub wydzielona przestrzeń kreatywna). 
Nauczanie przedsiębiorczości ...

Tabela 1. Zestawienie przedmiotów nauczania przedsiębiorczości na studiach inżynierskich wybranych uczelni technicznych w roku akademickim 2015/2016

\begin{tabular}{|c|c|c|c|}
\hline $\begin{array}{l}\text { Uczelnia - } \\
\text { Wydzial }\end{array}$ & Nazwa & $\begin{array}{l}\text { Forma } \\
\text { realizacji }\end{array}$ & Sylabus \\
\hline $\begin{array}{l}\text { PW - W. Trans- } \\
\text { portu, W. Samo- } \\
\text { chodów i Maszyn } \\
\text { Roboczych }\end{array}$ & $\begin{array}{l}\text { Przedsiębiorczość } \\
\text { innowacyjna }\end{array}$ & $\begin{array}{l}7 \text { sem. }-30 \mathrm{~A}- \\
\text { obieralny }\end{array}$ & $\begin{array}{l}\text { Uwarunkowania prowadzenia } \\
\text { działalności gospodarczej - } \\
\text { wykłady, warsztaty, projekty }\end{array}$ \\
\hline \multirow{2}{*}{$\begin{array}{l}\text { PW - } \\
\text { W. Mechaniczny } \\
\text { Energetyki } \\
\text { i Lotnictwa }\end{array}$} & $\begin{array}{l}\text { Przedsiębiorczość } \\
\text { w praktyce }\end{array}$ & $\begin{array}{l}2 \text { sem. }-30 \mathrm{~A}- \\
\text { obowiązkowy }\end{array}$ & $\begin{array}{l}\text { Podstawy zarządzania, } \\
\text { biznesplan, etykiety biznesie - } \\
\text { wykład, biznesplany }\end{array}$ \\
\hline & $\begin{array}{l}\text { Podstawy prawne } \\
\text { działalności } \\
\text { przedsiębiorstwa }\end{array}$ & $\begin{array}{l}7 \text { sem. }-30 \mathrm{~A}- \\
\text { obowiązkowy }\end{array}$ & $\begin{array}{l}\text { Aspekty prawne działalności } \\
\text { gospodarczej - wykład }\end{array}$ \\
\hline \multirow[t]{2}{*}{$\begin{array}{l}\text { PW - } \\
\text { W. Inżynierii } \\
\text { Materiałowej }\end{array}$} & $\begin{array}{l}\text { Planowanie } \\
\text { przedsięwzięć } \\
\text { biznesowych } \\
\text { i przedsiębiorczość } \\
\text { innowacyjna }\end{array}$ & $\begin{array}{l}4 \text { sem. }-30 \mathrm{~A}- \\
\text { obieralny }\end{array}$ & $\begin{array}{l}\text { Uwarunkowania prowadzenia } \\
\text { działalności gospodarczej - } \\
\text { wykłady, warsztaty, projekt }\end{array}$ \\
\hline & $\begin{array}{l}\text { Prawo działalności } \\
\text { gospodarczej }\end{array}$ & $\begin{array}{l}4 \text { sem. }-15 \mathrm{~A}- \\
\text { obieralny }\end{array}$ & $\begin{array}{l}\text { Aspekty prawne działalności } \\
\text { gospodarczej - wykład }\end{array}$ \\
\hline \multirow[t]{3}{*}{$\begin{array}{l}\text { PW - } \\
\text { W. Inżynierii } \\
\text { Lądowej }\end{array}$} & $\begin{array}{l}\text { Planowanie } \\
\text { przedsięwzięć } \\
\text { biznesowych }\end{array}$ & $\begin{array}{l}2 \text { sem }-30 \mathrm{~A}- \\
\text { obieralny }\end{array}$ & $\begin{array}{l}\text { Uwarunkowania prowadzenia } \\
\text { działalności gospodarczej - } \\
\text { wykłady }\end{array}$ \\
\hline & $\begin{array}{l}\text { Działalność } \\
\text { gospodarcza - źródła } \\
\text { finansowania, } \\
\text { regulacja zobowiązań } \\
\text { podatkowych }\end{array}$ & $\begin{array}{l}2 \text { sem. }-30 \mathrm{~A}- \\
\text { obieralny }\end{array}$ & $\begin{array}{l}\text { Zasady podejmowania własnej } \\
\text { działalności z dużym naciskiem } \\
\text { na zobowiązania podatkowe - } \\
\text { wykład }\end{array}$ \\
\hline & Samozatrudnienie & $\begin{array}{l}7 \text { sem. }-30 \mathrm{~A}- \\
\text { obieralny }\end{array}$ & $\begin{array}{l}\text { Zasady podejmowania własnej } \\
\text { działalności z dużym naciskiem } \\
\text { na zobowiązania podatkowe - } \\
\text { wykład }\end{array}$ \\
\hline \multirow{2}{*}{$\begin{array}{l}\text { PW - } \\
\text { W. Geodezji } \\
\text { i Kartografii }\end{array}$} & $\begin{array}{l}\text { Myślenie projektowe } \\
\text { (Design Thinking) }\end{array}$ & $\begin{array}{c}2 \text { sem. }-15 \mathrm{~A}- \\
\text { obieralny }\end{array}$ & $\begin{array}{l}\text { Metodyka Design Thinking - } \\
\text { wykład }\end{array}$ \\
\hline & Przedsiębiorczość & $\begin{array}{c}2 \text { sem. }-15 \mathrm{~A}- \\
\text { obieralny }\end{array}$ & brak danych \\
\hline $\begin{array}{l}\text { PB - } \\
\text { Wydział } \\
\text { Informatyki }\end{array}$ & $\begin{array}{l}\text { Działalność } \\
\text { gospodarcza } \\
\text { i ochrona własności } \\
\text { intelektualnej } \\
\text { w informatyce } \\
\text { (niezależnie na } \\
\text { kierunkach } \\
\text { Informatyka } \\
\text { i Matematyka) }\end{array}$ & $\begin{array}{c}7 \text { sem. - } \\
20 \mathrm{~A}+10 \mathrm{C}- \\
\text { obowiązkowy } \\
\text { (Informatyka) }\end{array}$ & $\begin{array}{l}\text { Wybrane zagadnienia z zakresu } \\
\text { prowadzenia działalności } \\
\text { gospodarczej dostosowane do } \\
\text { profilu studentów - wykład, } \\
\text { projekty }\end{array}$ \\
\hline $\begin{array}{l}\text { PW - } \\
\text { W. Geodezji } \\
\text { i Kartografii }\end{array}$ & $\begin{array}{l}\text { Myślenie projektowe } \\
\text { (Design Thinking) }\end{array}$ & $\begin{array}{l}2 \text { sem. }-15 \mathrm{~A}- \\
\text { obieralny }\end{array}$ & $\begin{array}{l}\text { Metodyka Design Thinking - } \\
\text { wykład }\end{array}$ \\
\hline
\end{tabular}


Tabela 1. Zestawienie przedmiotów nauczania przedsiębiorczości na studiach inżynierskich wybranych uczelni technicznych w roku akademickim 2015/2016 (cd.)

\begin{tabular}{|c|c|c|c|}
\hline $\begin{array}{l}\text { Uczelnia - } \\
\text { Wydzial }\end{array}$ & Nazwa & $\begin{array}{l}\text { Forma } \\
\text { realizacji }\end{array}$ & Sylabus \\
\hline \multirow{2}{*}{$\begin{array}{l}\text { PW - } \\
\text { W. Geodezji } \\
\text { i Kartografii }\end{array}$} & $\begin{array}{l}\text { Myślenie projektowe } \\
\text { (Design Thinking) }\end{array}$ & $\begin{array}{c}2 \text { sem. }-15 \mathrm{~A}- \\
\text { obieralny }\end{array}$ & $\begin{array}{l}\text { Metodyka Design Thinking - } \\
\text { wykład }\end{array}$ \\
\hline & Przedsiębiorczość & $\begin{array}{c}2 \text { sem. }-15 \mathrm{~A}- \\
\text { obieralny }\end{array}$ & brak danych \\
\hline \multirow[t]{3}{*}{$\begin{array}{l}\text { PB - } \\
\text { Wydział } \\
\text { Informatyki }\end{array}$} & \multirow{2}{*}{$\begin{array}{l}\text { Działalność } \\
\text { gospodarcza i } \\
\text { ochrona własności } \\
\text { intelektualnej w } \\
\text { informatyce } \\
\text { (niezależnie na } \\
\text { kierunkach } \\
\text { Informatyka i } \\
\text { Matematyka) }\end{array}$} & $\begin{array}{c}7 \text { sem. }- \\
20 \mathrm{~A}+10 \mathrm{C}- \\
\text { obowiązkowy } \\
\text { (Informatyka) }\end{array}$ & $\begin{array}{l}\text { Wybrane zagadnienia z zakresu } \\
\text { prowadzenia działalności } \\
\text { gospodarczej dostosowane do } \\
\text { profilu studentów - wykład, } \\
\text { projekty }\end{array}$ \\
\hline & & $\begin{array}{c}5 \text { sem. }- \\
20 \mathrm{~A}+10 \mathrm{C}- \\
\text { obowiązkowy } \\
\text { (Matematyka) }\end{array}$ & $\begin{array}{l}\text { Zagadnienia ochrony własności } \\
\text { intelektualnej poszerzone } \\
\text { o kształtowanie umiejętności } \\
\text { rozwoju pomysłów biznesowych } \\
\text { - wykład, projekt }\end{array}$ \\
\hline & $\begin{array}{l}\text { Przedsiębiorczość } \\
\text { akademicka }\end{array}$ & $\begin{array}{c}7 \text { sem. - } \\
20 \mathrm{~A}+10 \mathrm{C}- \\
\text { obowiązkowy }\end{array}$ & $\begin{array}{l}\text { Wybrane modele, techniki } \\
\text { i narzędzia wspierających rozwój } \\
\text { działalności gospodarczej już na } \\
\text { uczelni - case study, spotkania, } \\
\text { projekty }\end{array}$ \\
\hline \multirow[t]{4}{*}{$\begin{array}{l}\text { PB - } \\
\text { W. Mechaniczny }\end{array}$} & $\begin{array}{l}\text { Design Thinking } \\
\text { (myślenie } \\
\text { projektowe) }\end{array}$ & $\begin{array}{l}7 \text { sem. }-12 \mathrm{~A}- \\
\text { obieralny }\end{array}$ & $\begin{array}{l}\text { Techniki innowacyjnego } \\
\text { myślenia i kreatywnej pracy - } \\
\text { wykład, projekt }\end{array}$ \\
\hline & Modele biznesowe & $\begin{array}{c}7 \text { sem. }-12 \mathrm{~A}- \\
\text { obieralny }\end{array}$ & $\begin{array}{l}\text { Model biznesu (Business Model } \\
\text { Canvas) - wykład, projekt }\end{array}$ \\
\hline & $\begin{array}{l}\text { Przedsiębiorczość } \\
\text { innowacyjna }\end{array}$ & $\begin{array}{l}7 \text { sem. }-15 \mathrm{~A}- \\
\text { obieralny }\end{array}$ & $\begin{array}{l}\text { Biznesplan i model biznesu } \\
\text { (Business Model Canvas) - } \\
\text { wykład, projekt }\end{array}$ \\
\hline & $\begin{array}{l}\text { Myślenie } \\
\text { innowacyjne }\end{array}$ & $\begin{array}{l}7 \text { sem. }-15 \mathrm{C}- \\
\text { obieralny }\end{array}$ & $\begin{array}{l}\text { Techniki innowacyjnego } \\
\text { myślenia i kreatywnej pracy - } \\
\text { wykład, projekt }\end{array}$ \\
\hline $\begin{array}{l}\mathrm{AM}- \\
\text { W. Inżynieryjno- } \\
\text { Ekonomiczny } \\
\text { Transportu } \\
\end{array}$ & Przedsiębiorczość & $\begin{array}{c}2 \mathrm{sem}- \\
\text { 30A+30C - } \\
\text { obowiązkowy }\end{array}$ & $\begin{array}{l}\text { Uwarunkowania prowadzenia } \\
\text { działalności gospodarczej - } \\
\text { wykład, ćwiczenia w grupach }\end{array}$ \\
\hline $\begin{array}{l}\text { AM - } \\
\text { W. Nawigacyjny }\end{array}$ & Przedsiębiorczość & $\begin{array}{l}1 \text { sem. }-30 \mathrm{~A}- \\
\text { obowiązkowy }\end{array}$ & $\begin{array}{l}\text { Uwarunkowania prowadzenia } \\
\text { działalności gospodarczej - } \\
\text { wykład, projekt }\end{array}$ \\
\hline
\end{tabular}

PW - Politechnika Warszawska, PB - Politechnika Białostocka, AM - Akademia Morska w Szczecinie; A - wykłady, C - ćwiczenia

Źródło: opracowanie własne na podstawie programów nauczania uczelni: Politechniki Warszawskiej (www.pw.edu.pl), Politechniki Białostockiej (pb.edu.pl) i Akademii Morskiej w Szczecinie (am.szczecin.pl). 


\section{DYSKUSJA WYNIKÓW}

Warto podkreślić, że zdecydowana większość analizowanych przedmiotów została wprowadzona do programów nauczania w ostatnich pięciu latach. Analiza programów, które były aktualne w roku akademickim 2009/2010 pokazuje, że jedynie na jednej uczelni, tj. na kierunku Inżynierii materiałowej Politechniki Warszawskiej realizowano przedmioty z grupy nauk o przedsiębiorczości: Planowanie przedsięwzięć biznesowych, Przedsiębiorczość oraz Prawo własności intelektualnej i prawo pracy. Pozostałe wydziały na tej uczelni, jak również wydziały z pozostałych dwóch objętych analizą uczelni nie uwzględniają tego typu przedmiotów w siatkach godzin. Można jednak założyć, że część omawianych w tabeli 1 treści programowe było realizowanych w ramach przedmiotów ekonomicznych (Podstawy ekonomii; Finanse i rachunkowość; Rachunek kosztów dla inżynierów) lub w ramach tzw. nietechnicznych przedmiotów fakultatywnych (przedmiot obieralny społeczno-humanistyczny).

Ujęty w programach nauczania wymiar przedmiotów nauczania przedsiębiorczości jest niewystarczający w stosunku do zakresu umiejętności, które powinny być kształtowane. Przykładowo, w 45-godzinnym bloku przedmiotu Przedsiębiorczość ciasno upakowane jest projektowanie biznesu, przywództwo, rozwijanie kreatywności i aspekty związane z innowacyjnością. Autorzy postulują, aby wzorem dobrych europejskich i amerykańskich uczelni studenci kierunków technicznych mieli możliwość realizacji całego pakietu przedmiotów pod szyldem Przedsiębiorczość.

Z doświadczeń autorów wynika, że bardzo ważnym walorem przedmiotu Przedsiębiorczość jest jego realizacja $\mathrm{w}$ grupach multidyscyplinarnych. Zajęcia $\mathrm{z}$ tego przedmiotu były prowadzone $\mathrm{w}$ ramach realizowane $\mathrm{w}$ projekcie MELES szkoły letniej właśnie w takich grupach, zaś na uczelniach, w ramach implementacji przedmiotu, jego realizacja na razie odbywa się $\mathrm{w}$ grupach homogenicznych. Różnica w uzyskanych efektach jest zdaniem autorów bardzo duża. Potwierdzają to też studenci. Dlatego kolejną rekomendacją jest dążenie do tworzenia grup multidyscyplinarnych. Do rozwiązania tego typu problemów niezbędne jest działanie systemowe na poziomie Ministerstwa Nauki i Szkolnictwa Wyższego.

Nie wolno zapominać o zapewnieniu właściwych warunków do prowadzenia zajęć z przedsiębiorczości. Nie mają one formy wykładu, a bliżej im do pracowni projektowej. Dlatego maksymalna liczność grupy na zajęciach nie powinna przekraczać 30 osób. Ponadto sala, w której prowadzone są zajęcia, musi być przygotowana do pracy nad projektami w 5-6-osobowych zespołach.

Kolejny postulat związany jest $\mathrm{z}$ kształceniem kadr do prowadzenia przedmiotów związanych z przedsiębiorczością. Na każdej uczelni technicznej jest grupa nauczycieli akademickich, która ma doświadczenie we współpracy $\mathrm{z}$ otoczeniem społeczno-gospodarczym. To właśnie takie osoby powinny po odpowiednim przygotowaniu uczyć przedsiębiorczości na uczelniach. Autorzy postulują wypracowanie jednolitego w całym kraju modelu kształcenia nauczycieli przedsiębiorczości.

Ostatnia rekomendacja dotyczy wprowadzania zajęć dodatkowych z zakresu przedsiębiorczości na uczelniach. Zajęcia te powinny mieć formę sesji mentorskich i coachingowych a ich celem jest wsparcie realnych projektów biznesowych studentów i pracowników uczelni. Będzie to istotny krok w kierunku budowy ekosystemu wspierania przedsiębiorczości i efektywnego rozwoju współpracy uczelni $\mathrm{z}$ jej otoczeniem społeczno-gospodarczym. 
Analiza nie pozwoliła na ocenę zaplecza technicznego dla zajęć, choć jest to istotne zagadnienie. Szkoły techniczne są $\mathrm{z}$ reguły dobrze wyposażone w laboratoria dydaktyczne. Są one kluczowe dla efektywnego nauczania, również w zakresie przedmiotów związanych $\mathrm{z}$ nauczaniem przedsiębiorczości. Wydaje się, że zaprezentowane przykłady nauczania projektowego po części wykorzystują dostępne i przygotowane przez nauczyciela prowadzącego pomoce dydaktyczne, lecz nie mają one charakteru w pełni profesjonalnego w porównaniu do istniejących na uczelni laboratoriów specjalistycznych.

\section{WNIOSKI}

Jak wynika $\mathrm{z}$ analizy przeprowadzonej powyżej, wyzwania w zakresie nauczania przedsiębiorczości określone przez Komisję Europejską są w Polsce bardzo aktualne. Jesteśmy wyraźnie na początku drogi do innowacyjnej i przedsiębiorczej Europy - drogi, w której bardzo istotnym elementem jest edukacja na wszystkich szczeblach nauczania. Możemy mówić o trwającym od kilku lat procesie uzupełniania treści programowych na kierunkach technicznych polskich uczelni o przedmioty kształtujące wiedzę o przedsiębiorczości. Proces ten jest stosunkowo dynamiczny, biorąc pod uwagę tradycyjną niechęć środowisk inżynierskich do zastępowania przedmiotów technicznych przedmiotami nietechnicznymi. Zmiany wydają się być wymuszone sytuacją na rynku pracy i są efektem analiz losów absolwentów oraz potrzeb zgłaszanych przez pracodawców. W oczywisty sposób tempo i jakość zmian programowych jest różna i wiąże się wprost $\mathrm{z}$ otwartością władz wydziałów oraz ich gremiów programowych na odejście od dotychczasowej formuły nauczania inżynierskiego.

Duża różnorodność wymiarów i zakresów programów nauczania na uczelniach technicznych świadczy o braku spójnej strategii wdrażania przedmiotów w zakresie przedsiębiorczości. Taka strategia jest bardzo istotna, ponieważ jak wynika z przytoczonych dobrych praktyk uczelni europejskich i amerykańskich, przedmioty związane $\mathrm{z}$ przedsiębiorczością powinny być realizowane $\mathrm{w}$ synergii $\mathrm{z}$ całym ekosystem wspierania procesu tworzenia nowych firm w danym regionie czy kraju. Potwierdzają to doświadczenia autorów. Realizacja przedmiotu Przedsiębiorczość opracowanego w ramach projektu MELES efektywnie kształtuje postawę pro przedsiębiorczą u studentów, którzy zmotywowani zajęciami i zaczynają coraz częściej angażować się w prawdziwe projekty biznesowe. W każdej fazie realizacji takich projektów potrzebne jest jednak intensywne wsparcie $\mathrm{w}$ formie coachingu i mentoringu w różnych obszarach i fazach rozwoju projektów.

Szczegółowe wnioski odnoszące się do realizacji przedmiotów nauczania przedsiębiorczości w szkołach technicznych, zostały sformułowane w dyskusji wyników przeprowadzonej analizy. Najważniejsze kwestie obejmują: dobór nauczycieli lub instruktorów posiadających odpowiednie przygotowanie do prowadzenia zajęć, realizacja zajęć w multidyscyplinarnych grupach projektowych o maksymalnej liczebności 30 osób, zajęcia w liczbie min. 45 godzin dydaktycznych, wykorzystanie przestrzeni o charakterze „laboratoriów kreatywności”, uzupełnienie zajęć o dodatkowe sesje mentorskie i coachingowe.

Autorzy widzą potrzebę dalszych badań i analiz w zakresie nauczania przedsiębiorczości. Wskazane jest rozszerzenie obszaru badawczego o szkolnictwo średnie i kursy oferowane w ramach nauczania ustawicznego. Badani powinny przyczynić się do powstania narodowej strategii nauczania przedsiębiorczości. Biorąc pod uwagę 
multidyscyplinarne i projektowe podejście do kształcenia w zakresie przedsiębiorczości konieczne jest stworzenie szerokiej przestrzeni współpracy, obejmującego szkolnictwo, przedsiębiorców i instytucje państwowe, w celu wdrożenia efektywnych programów nauczania.

\section{LITERATURA}

[1] Entrepreneurship Education: A Global Consideration From Practice to Policy Around the World, WISE - World Summit for Education, 2016, http://www.wise-qatar.org/ (dostęp: 21.04.2016 r.).

[2] Entrepreneurship in higher education, especially within non-business studies, Final Report of the Expert Group, European Commission, 2008, http://europa.eu.int (dostęp: 21.04.2016 r.).

[3] Entrepreneurship in American Higher Education, Report from the Kauffman Panel on Entrepreneurship Curriculum in Higher Education, 2008, http://www.kauffman.org (dostęp: 21.04.2016 r.).

[4] Fabiańska K., Planowanie rozwoju przedsiębiorstwa, PWE, Warszawa 1986.

[5] Majka F., Analiza przestrzenna zatrudnienia absolwentów Wydziatu Nawigacyjnego kierunku Geodezja i Kartografia, praca inżynierska, Wydział Nawigacyjny, Akademia Morska w Szczecinie, Szczecin 2016.

[6] Kocór M., Strzebońska A., Zapotrzebowanie na pracowników, Polska Agencja Rozwoju Przedsiębiorczości, Warszawa 2014.

[7] Kortan J., Podstawy ekonomiki i zarządzania przedsiębiorstwem, Wyd. C.H. Beck, Warszawa 1997.

[8] Lilischkis S. et al., Supporting the Entrepreneurial Potential of Higher Education, Final Report, 2015, www.minedu.fi (dostęp: 21.04.2016 r.).

\section{ENTREPRENEURSHIP EDUCATION ON TECHNICAL FACULTIES}

\section{OF POLISH UNIVERSITIES}

The article is the result of a two-year research cooperation of the Maritime Academy in Szczecin and Bialystok University of Technology with foreign partners, in the framework of the project MELES (More Entrepreneurial Life at European Schools) funded by the Erasmus+ Programme. The main result of the project is the curriculum of Entrepreneurship course for multidisciplinary group of students and its implementation at universities. The authors describe determinants of academic teaching of business-oriented courses and an experience in this field of leading European and the USA universities. Presented examples of "good practice" come from: Stanford University and the University of California in the United States, Delft University of Technology in the Netherlands, the Technical University in Munich (Germany) and the Finnish Polytechnics Entrepreneur-Ship Network in Finland. Examination of changes made to curriculum in 2009-2015 based on selected engineer fields of study is carried out at three universities (Maritime University of Szczecin, Bialystok Technical University and Warsaw University of Technology). The teaching methods and programs of entrepreneurship courses in the academic year 2015/2016 at the selected universities are discussed. Detailed and general conclusions as well as recommendations for the program councils of technical universities responsible for the development and implementation of entrepreneurship courses are drawn on this basis. Special attention is 
devoted to aspect of multidisciplinary approach as well as to overcoming barriers of courses implementation.

Keywords: entrepreneurship, teaching, higher education, multidisciplinary.

DOI:10.7862/rz.2017.hss.7

Przestano do redakcji: styczeń $2017 \mathrm{r}$.

Przyjęto do druku: marzec 2017 r. 